\title{
Whole-Blood Polymerase Chain Reaction and Restriction Fragment Length Polymorphism: A Simplified Method by Microwave Irradiation
}

\author{
Mehrez M. Jadaon Ali A. Dashti Hend L. Lewis Fatema M. Habeeb \\ Department of Medical Laboratory Sciences, Faculty of Allied Health Sciences, Kuwait University, Kuwait
}

\section{Key Words}

DNA extraction - Whole-blood polymerase chain reaction • Whole-blood restriction fragment length polymorphism

\begin{abstract}
Objectives: The aim of the present study was to develop a simple, quick and cheap method to process whole-blood samples for the molecular techniques polymerase chain reaction (PCR) and restriction fragment length polymorphism (RFLP) without the use of expensive reagents or sophisticated machines. Materials and Methods: Venous whole-blood samples were collected from 40 individuals. The samples were frozen at $-80^{\circ} \mathrm{C}$, and then rapidly thawed at $37^{\circ} \mathrm{C}$. Each sample was incubated with distilled water, then boiled in a microwave and centrifuged. The supernatant was taken directly for PCR and RFLP. For comparison, PCR and RFLP were performed on DNA purified from the same samples using the phenol-chloroform method and two commercial DNA extraction kits. Results: PCR/RFLP results using the presented method were qualitatively similar to those obtained by DNA extracted using the other three methods. Conclusion: The presented method proved to be a simpler and cheaper way of processing whole-blood samples for PCR and RFLP analyses.

Copyright $\odot 2009$ S. Karger AG, Basel
\end{abstract}

\section{Introduction}

A large number of molecular techniques such as polymerase chain reaction (PCR), restriction fragment length polymorphism (RFLP), hybridization techniques, and DNA sequencing are currently being widely used in different diagnostic and research centers. These techniques require DNA extracted and purified from biological specimens such as blood, tissues, hair, or body fluids. Many DNA extraction procedures are based on the traditional phenol-chloroform extraction method that needs a number of reagents and equipments [1,2]. Attempts were made to simplify the procedure for DNA extraction and purification, while maintaining the quality and purity of the extracted DNA so that it remains suitable for the subsequent molecular techniques [3-6]. Some methods involved releasing DNA by rupturing cells using certain lysing agents containing different chemicals including lysozyme, proteinase $\mathrm{K}$ and Tween 20 [7-11]. Various physical processes have been used, including heating, cooling, freezing and microwave irradiation [7-16]. Combinations of the chemical and physical methods have also been applied [7-9, 12, 13]. However, most of the methods described above are laborious, time consuming and costly. In the last two decades, faster and simpler methods and commercial kits for DNA extraction have been developed. However, they are costly and require several steps and reagents, and sometimes special equipment $[10$, $12,14,17,18]$.

The present study was undertaken to develop a simple method for DNA extraction from white blood cells in

\section{KARGER \\ Fax +4161306 1234 \\ E-Mail karger@karger.ch}

www.karger.com
(C) 2009 S. Karger AG, Basel

$1011-7571 / 09 / 0184-0280 \$ 26.00 / 0$

Accessible online at:

www.karger.com/mpp
Mehrez M. Jadaon

Department of Medical Laboratory Sciences

Faculty of Allied Health Sciences, Kuwait University

PO Box 31470, Sulaibekhat 90805 (Kuwait)

Tel. +965 664 3485, Fax +965 498 3835, E-Mail mehrez@hsc.edu.kw 
whole blood. DNA was released from white blood cells by rupturing the cells using freeze/thaw and then isolated by microwave. The suitability of the extracted DNA for molecular biology techniques was tested by PCR and RFLP. For comparison, the traditional phenol-chloroform method and two commercial DNA extraction kits were also used in parallel.

\section{Materials and Methods}

\section{Samples Collection}

Venous whole-blood samples were collected by standard phlebotomy from 20 patients with venous thomboembolic diseases and 20 healthy subjects. The blood samples were collected in vacutainers containing potassium EDTA as an anticoagulant, and the samples were frozen at $-20^{\circ} \mathrm{C}$ or $-80^{\circ} \mathrm{C}$ for at least $1 \mathrm{~h}$. Consent forms were signed by all subjects included in the study. The subjects chosen were carriers or noncarriers of the Factor $\mathrm{V}$ Leiden mutation (FVL; G1691A) in their clotting factor V gene $[19,20]$. There were 14 heterozygous and 6 homozygous carriers of the FVL mutation. The presence or absence of FVL in these subjects was confirmed by previous studies [21, 22]. FVL mutation carriers were chosen for this study because the PCR/RFLP tests are well established for FVL.

\section{Pretreatment of Whole-Blood Samples}

Each blood sample was rapidly thawed at $37^{\circ} \mathrm{C}$ before processing. An aliquot $(10 \mu \mathrm{l})$ of blood was first mixed with $490 \mu \mathrm{l}$ of distilled water in a 1-ml Eppendorf tube, and the mixture was incubated at room temperature for $2 \mathrm{~min}$. The cap of the Eppendorf tube was pinched with a needle. The mixture was then boiled in a National kitchen microwave oven (700 W) (from Matsushita Electric Industrial Company, Japan) for $7 \mathrm{~min}$ while placed in a heat-resistant jar containing $500 \mathrm{ml}$ water. Subsequently, the Eppendorf tube was centrifuged at $14,000 \mathrm{rpm}$ for $30-60 \mathrm{~s}$. Finally, the clear supernatant was used directly for PCR.

\section{Polymerase Chain Reaction}

Five microliters of the supernatant from the previous step were mixed with $45 \mu \mathrm{l}$ of prealiquoted Reddy-Load PCR Mix (from ABgene, UK) containing 1.25 units of Taq DNA polymerase, 75 $\mathrm{mM}$ Tris- $\mathrm{HCl}$ (pH 8.8), $20 \mathrm{mM}\left(\mathrm{NH}_{4}\right)_{2} \mathrm{SO}_{4}, 1.5 \mathrm{mM} \mathrm{MgCl}_{2}, 0.01 \%$ $(\mathrm{v} / \mathrm{v})$ Tween 20 , and $0.2 \mathrm{mM}$ of each of the four deoxynucleotide triphosphates (dATP, dCTP, dGTP and dTTP). One hundred picomoles of each of the following two primers were then added to this mixture: (1) 5'-TGC CCA GTG CTT AAC AAG ACC A-3' (nucleotides 1581-1602 of exon 10 of the human clotting factor $\mathrm{V}$ gene); (2) 5'-TGT TAT CAC ACT GGT GCT AA-3' (nucleotides $127-146$ of intron 10 of the human clotting factor $\mathrm{V}$ gene). These primers flank a 267-bp DNA fragment of the human clotting factor $\mathrm{V}$ gene which is present in chromosome 1q21-25. This part was chosen because it contains the site of the FVL mutation (G1691A), which was found present in half of the subjects included in this study. The PCR mixture was then incubated for $1 \mathrm{~min}$ at $94^{\circ} \mathrm{C}$ as an initial denaturation step, followed by 40 cycles of successive alternating temperatures as follows: denaturation step at $94^{\circ} \mathrm{C}$ for $1 \mathrm{~min}$, annealing step at $50^{\circ} \mathrm{C}$ for $1 \mathrm{~min}$, and extension step at $72^{\circ} \mathrm{C}$ for $2 \mathrm{~min}$. A final extension step at $72^{\circ} \mathrm{C}$ for $7 \mathrm{~min}$ was allowed. The PCR was performed in a programmable PCR Thermal Cycler (Perkin Elmer, Wellesley, Mass., USA).

\section{Restriction Fragment Length Polymorphism}

Eighteen microliters of the PCR amplicon (product), as obtained by the above procedure, were mixed with $2 \mu l$ of the $M n l \mathrm{I}$ restriction enzyme (from Stratagene, La Jolla, Calif., USA), and the new mixture $(5 \mathrm{U} / \mu \mathrm{l})$ was incubated at $37^{\circ} \mathrm{C}$ for $16 \mathrm{~h}$. PCR products, before and after treatment with the $\mathrm{Mnl}$ I restriction enzyme, were subjected to electrophoresis on a $2.5 \%$ agarose gel. The bands obtained by gel electrophoresis were stained with ethidium bromide, which was already incorporated into the agarose gel before electrophoresis. These DNA bands were visualized by exposure to UV light in a gel documentation system (UVP Company, Upland, Calif., USA).

In normal non-FVL carriers, PCR amplicons should have two restriction sites for the $\mathrm{Mnl}$ I restriction enzyme. In carriers of the FVL mutation, the presence of the mutation removes one of these restriction sites. Based on that, the results of the RFLP can be interpreted according to the cutting patterns as follows: normal wild-type 1691 GG $\rightarrow$ 163-, 67- and 37-bp fragments; homozygous FVL 1691 AA $\rightarrow$ 200- and 67-bp fragments; heterozygous FVL 1691 GA $\rightarrow$ 200-, 163-, 67- and 37-bp fragments.

\section{Comparison with Conventional DNA Extraction Methods} followed by PCR

For comparison purposes, DNA was extracted from the same blood samples using the conventional phenol-chloroform method $[1,2]$. In addition, DNA was extracted using two commercially available DNA extraction kits, namely Genisol DNA isolation kit (Advanced Biotechnologies, UK) and QIAmp Blood Mini kit (Qiagen, Germany). Two hundred nanograms of the purified DNA from each extraction method were used to perform PCR and RFLP analyses, using the same procedures as described above.

\section{Results}

A picture of 2.5\% agarose gel electrophoresis of PCR products from DNA extracted by the currently described method, the traditional phenol-chloroform method, and the commercial kits is shown in figure 1. Results of two samples are included, but all 40 cases studied gave similar results. PCR amplicons were produced successfully in all DNA samples included in this project. The amplified product obtained with primers specific for FVL mutation was $267 \mathrm{bp}$ which was the expected product size of the amplified gene with the set of primers used. So, before cutting with $M n l$ I, each PCR amplicon from DNA extracted by the present method, traditional extraction method or the two commercial kits was a 267-bp fragment (fig. 1).

In the RFLP step, $M n l$ I restriction endonuclease was used to cleave the PCR amplicons. The $\mathrm{Mnl}$ I restriction enzyme managed to cut the PCR amplicons produced 
Fig. 1. Agarose gel electrophoresis of PCR amplicons before and after cutting with the $M n l$ I restriction enzyme. The results are for two cases: a heterozygous carrier (lanes 2-7) and a homozygous carrier of the FVL mutation (lanes 13-18). Lanes 8 and 9 are negative PCR controls, and lane 10 is a positive PCR control. Lane 11 has the same PCR amplicon present in lane 10 but after processing for RFLP, without the addition of $\mathrm{Mnl} \mathrm{I}$. This lane shows that no cutting happened to the 267-bp fragment, thus acting as a negative control for RFLP. Three DNA markers were used in lanes 1 and 19 (100-bp ladder) and lane 12 (123-bp ladder).

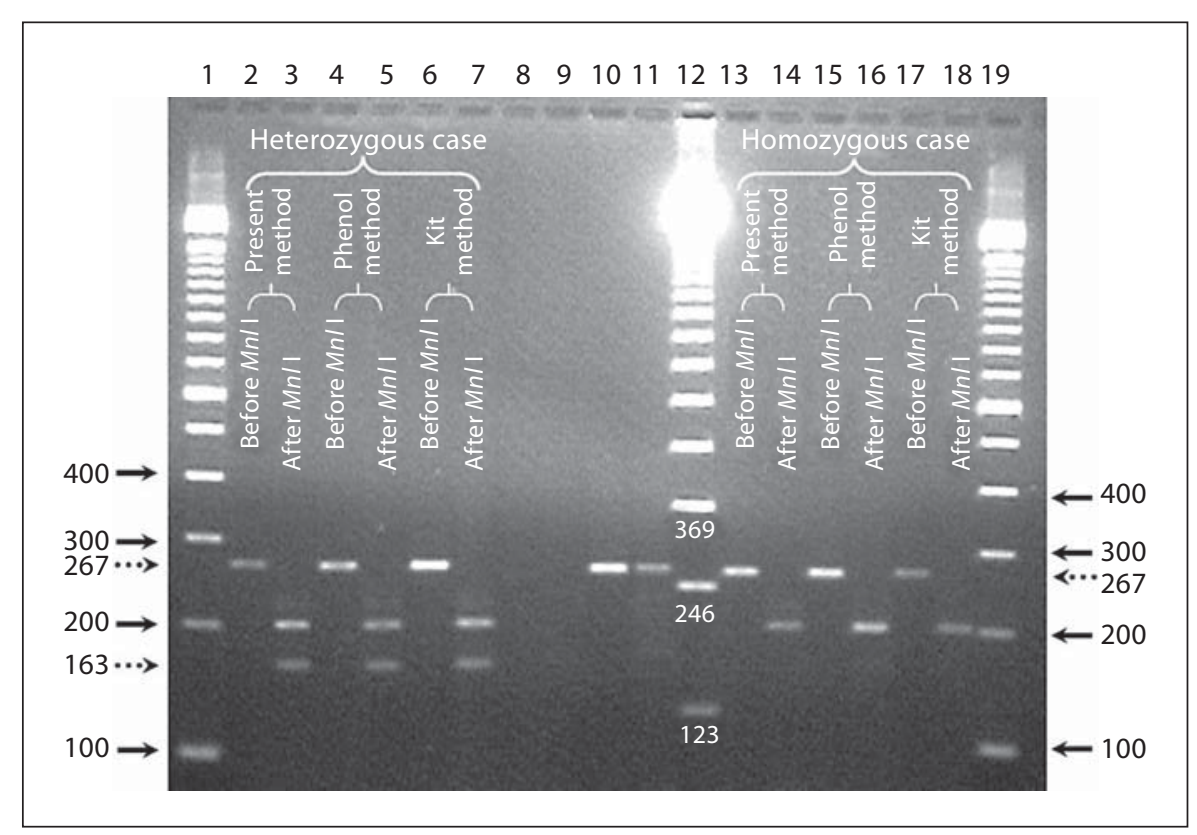

from the whole blood by the present method (fig. 1). After cutting, outcome fragments were 200 and 163 bp in the heterozygous case, and $200 \mathrm{bp}$ in the homozygous case. A similar pattern was obtained whether the DNA samples were extracted by the phenol-chloroform method or the commercial kits. Cutting was successful in all the 40 samples. In addition, the cutting patterns were as expected in each case whether it had the mutation or not (14 heterozygous and 6 homozygous FVL carriers; 20 noncarriers of the mutation).

\section{Discussion}

Attempts had been made to decrease the number of reagents and steps needed for DNA extraction and purification without affecting the quality and sample throughput. It was shown that microwave irradiation of samples can denature tissue DNA in in situ hybridization [23], and in the pretreatment step for DNA extraction from fungi, plants and animals $[24,25]$. In addition, microwave irradiation destroyed cell structures and exposed DNA [25]. Moreover, heating blood at $95^{\circ} \mathrm{C}$ for $15 \mathrm{~min}$ had been reported to cytolyse cells $[5,26]$.

The present method combined freezing/heating, exposure of sample to hypotonic environment (distilled water) with microwave irradiation that ruptured cell membrane and released DNA. Analyses of DNA samples obtained from blood by this method showed that both PCR and RFLP were successful in all samples used. The results of FVL mutation seen here were comparable to published reports where further confirmation was obtained by DNA sequencing $[21,22]$.

Other researchers reported similar methods, but they needed additional reagents concurrently or afterwards to facilitate the cytolysis. The method presented here does not require any additional reagent except distilled water used to challenge cells in a hypotonic situation that induced cytolysis further. Also, water diluted the hemoglobin content and thus might have reduced its inhibitory effect on PCR $[5,26]$. The complete procedure took less than 15 min.

The present method may be suitable for whole-blood samples stored at $-80^{\circ} \mathrm{C}$ for several months. Other areas of potential application of this simple procedure include DNA sequencing, hybridization techniques, real-time PCR, and PCR, production of DNA amplicons of large sizes and processing of other biological specimens such as culture cells, hair, body fluids, and bacteria.

\section{Conclusion}

The present method is a very simple, cheap, quick and successful method for preparing whole blood to be used directly in PCR and RFLP techniques, yielding results comparable with those from more laborious methods that need DNA extraction and purification. 


\section{References}

1 Gross-Bellard M, Oudet P, Chambon P: Isolation of high-molecular-weight DNA from mammalian cells. Eur J Biochem 1973;36: 32-38.

2 Sambrook A, Frintsch BF, Maniatis T: Molecular Cloning: A Laboratory Manual. New York, Cold Spring Harbor Laboratory Press, 1989.

$>3$ Miller SA, Dykes DD, Polesky HF: A simple salting out procedure for extracting DNA from human nucleated cells. Nucleic Acids Res 1988; 16:1215.

-4 Ferre F, Garduno F: Preparation of crude cell extract suitable for amplification of RNA by the polymerase chain reaction. Nucleic Acids Res 1989;17:2141.

5 Shibata DK, Arnheim N, Martin WJ: Detection of human papilloma virus in paraffinembedded tissue using the polymerase chain reaction. J Exp Med 1988;167:225-230.

$\checkmark 6$ Smith K, Diggle MA, Clarke SC: Comparison of commercial DNA extraction kits for extraction of bacterial genomic DNA from whole-blood samples. J Clin Microbiol 2003; 41:2440-2443.

7 Porteous LA, Armstrong JL, Seidler RJ, Watrud LS: An effective method to extract DNA from environmental samples for polymerase chain reaction amplification and DNA fingerprint analysis. Curr Microbiol 1994;29: 301-307.

$>8$ Tell LA, Foley J, Needham ML, Walker RL: Comparison of four rapid DNA extraction techniques for conventional polymerase chain reaction testing of three Mycobacterium spp. that affect birds. Avian Dis 2003;47: 1486-1490.
>9 Zhu K, Jin H, Ma Y, Ren Z, Xiao C, He Z, Zhang F, Zhu Q, Wang B: A continuous thermallysis procedure for the large-scale preparation of plasmid DNA. J Biotechnol 2005; 118:257-264.

10 Merk S, Meyer H, Greiser-Wilke I, Sprague LD, Neubauer H: Detection of Burkholderia cepacia DNA from artificially infected EDTA-blood and lung tissue comparing different DNA isolation methods. J Vet Med B Infect Dis Vet Public Health 2006;B53:281285 .

11 Orsini M, Romano-Spica V: A microwavebased method for nucleic acid isolation from environmental samples. Lett Appl Microbiol 2001;33:17-20.

12 Jose JJ, Brahmadathan KN: Evaluation of simplified DNA extraction methods for EMM typing of group A streptococci. Indian J Med Microbiol 2006;24:127-130.

13 Dederich DA, Okwuonu G, Garner T, Denn A, Sutton A, Escotto M, Martindale A, Delgado O, Muzny DM, Gibbs RA, Metzker ML: Glass bead purification of plasmid template DNA for high throughput sequencing of mammalian genomes. Nucleic Acids Res 2002;30:e32.

14 Mercier B, Gaucher C, Feugeas O, Mazurier C: Direct PCR from whole blood, without DNA extraction. Nucleic Acids Res 1990;18: 5908.

15 Banik S, Bandyopadhyay S, Ganguly S: Bioeffects of microwave - A brief review. Bioresour Technol 2003;87:155-159.

16 Woo IS, Rhee IK, Parki HD: Differential damage in bacterial cells by microwave radiation on the basis of cell wall structure. Appl Environ Microbiol 2000;66:22432247.

-17 Smith K, Diggle MA, Clarke CS: Comparison of commercial DNA extraction kits for extraction of bacterial genomic DNA from whole-blood samples. J Clin Microbiol 2003; 41:2440-2443.
18 Strus M: Action of physical agents on microorganisms. Rocz Panstw Zakl Hig 1997;48: 263-268.

19 Rees DC, Cox M, Clegg JB: Detection of the factor V Leiden mutation using whole blood PCR. Thromb Haemost 1996;75:520-521.

20 Sinclair GD, Low S, Poon MC: A hemi-nested, allele specific, whole blood PCR assay for the detection of the factor $\mathrm{V}$ Leiden mutation. Thromb Haemost 1997;77:1154-1155.

21 Jadaon MM, Dashti AA: HR2 haplotype in Arab population and patients with venous thrombosis in Kuwait. J Thromb Haemost 2005;3:1467-1471.

22 Jadaon MM: A study of factor $\mathrm{V}$ mutation (arginine $506 \rightarrow$ glutamine) and activated protein $C$ resistance in patients with venous thrombosis in Kuwait; thesis, Kuwait University, Kuwait, 1998.

23 Coates PJ, Hall PA, Butler MG, D’Ardenne MG: Rapid technique of DNA-DNA in situ hybridization on formalin fixed tissue sections using microwave incubation. J Clin Pathol 1987;40:865-869.

24 Goodwin DC, Lee SB: Microwave miniprep of total genomic DNA from fungi, plants, protists and animals for PCR. Biotechniques 1993;15:438-444.

25 Rudbeck L, Dissing J: Rapid, simple alkaline extraction of human genomic DNA from whole blood, buccal epithelial cells, semen and forensic stains for PCR. Biotechniques 1998;25:588-592.

26 Panaccio M, Georgesz M, Lew A: FoLT PCR: a simple PCR protocol for amplifying DNA directly from whole blood. Biotechniques 1993; 14:238-243. 